\title{
Collaborative curriculum analysis in the mode of creative education in English
}

\author{
Zhao Hui Min ${ }^{1, \text { a }}$ \\ ${ }^{1}$ Bohai university, Jinzhou, 121013 China \\ azhaihuimin@126.com
}

\begin{abstract}
Keywords: English teaching; creative education; educational model; collaborative curriculum; analysis countermeasure.
\end{abstract}

\begin{abstract}
English teaching process is a complex process which contains many factors, for the development of the problems, only the use of innovative ways to solve, we need to constantly deepen understanding of the curriculum concept, combined with the actual situation in the region, in the practice of exploration, development, research and innovation in practice. The exploration and development of various English teaching modes and methods suitable for the actual situation, the implementation of innovative education is the main theme of the times, is the inevitable choice to promote the quality education to the depth. Innovation is an important source of national progress. With the continuous promotion of the integration of knowledge economy, innovation and information has become an indispensable source of power for the development of modernization. In order to cultivate a large number of excellent, high quality, compound and innovative English talents, the State encourages the development of students' English communicative competence through cooperative curriculum. English as the world's common language, needs to be based on innovative education, the use of evaluation tools and collaborative curriculum complement each other, to provide more complex talents to society. This kind of education mode not only can make the students master the skills of learning English, but also can improve the oral English ability in practice.
\end{abstract}

\section{Introduction}

The basic education of foreign language teaching along with the country the pace of reform and opening up, economic and social, sustained and rapid development of science and technology, through the recovery, development, reform and innovation in the course of 30 years, has made remarkable progress and achievements. Especially since 2001, the state launched eighth times since the reform of basic education, primary school English course in the third grade as a starting point, step by step, the new curriculum of compulsory education for nine years since 2005 the full implementation of the new period, the basic education in comprehensive reform and innovation. The implementation of the new curriculum reform steadily, with the students as the main body, pay attention to the overall development of students, the concept of the new curriculum is popular throughout the teaching and research activities flourished, in the continuous achievements of curriculum reform at the same time, we should also realize that the new curriculum is facing many difficulties and problems, the curriculum reform is a complex long process, it needs the whole society to support and help, need to practice educators unremittingly, harmonious unity of inheritance and development. The teaching process is a complex process and contains a variety of factors, the development of the problems, only the use of innovative ways to solve; we need to constantly deepen understanding of the curriculum concept, combined with the actual situation in the region, in the practice of exploration, development, research and innovation in practice [1].

\section{Innovation education teaching theory basis}

\section{Do a careful lesson preparation.}

Not only prepare students and preparing the teaching materials preparation methods, according to the actual teaching content and students, based on the cultivation of interest on training students' ability 
to read new words, but also let students try to imitate the textbook writing words; learning new knowledge based on maintaining the interests, increase the intensity of word dictation. Design class type, the proposed teaching methods, and the teaching process of the program and the timing of all made a detailed record, carefully written lesson plans. Be well prepared for each lesson, each lesson before class fully prepared, and produce a variety of interesting teaching aids to attract the attention of students, the course of after-school time to make a summary, write teaching postscript, and carefully collected according to the knowledge points in each lesson, summed up in.

\section{Enhance the class skills, improve the quality of teaching.}

To explain the clear, structured, accurate, systematic, accurate, emotional, vivid, do the clues to clear, clear, concise and comprehensive, easy. In the classroom, pay special attention to mobilize the enthusiasm of students, strengthen the communication between teachers and students, fully embodies the main role of the students, basically let students learn easily, easy to learn, learn happily; pay attention to scouring in the classroom, I speak as little as possible, let the students have more opportunities to move the brain to move the mouth; at the same time each lesson is fully considered in each level of the students' learning needs and learning ability, let the students of all levels are improved.

\section{Correcting the mistakes of his homework.}

Students in a very short time, available teaching resources are scarce, allowing students to access to information and the ability to solve difficult problems of solutions is limited, so the teacher must have the homework, but also carefully arranged tasks. Homework to do intensive reading. Targeted, there are levels of. The students' homework timely, seriously, analyzes and records of operation of students, they will appear in the process of classification summary, thorough review, and for the timely improvement of teaching methods, be targeted. To train the team leader to help me to check the other students to read and recite the text. On the current teaching conditions must be in order to review the students' learning effect. Teaching reform is in constant depth, new materials are emerging, more and more attention to the authenticity of the language, tunnel and communication. Organization of classroom teaching in English teachers not only to use language as a tool to explain knowledge, to convey information and to teach skills, but also to the knowledge and skills they want to impart knowledge and skills. At present, because most of the students in learning English classroom are still the only way and place, use English, teachers should pay more attention to the transmission of knowledge and information; create a good learning environment for students [2]. When I use English, I pay more attention to the acceptability, the simplicity, the stage and the practicability of the English language. The specific approach is: to create and design English language scenarios. Take the classroom as training and exercise the students' ability to use language, encourage students to speak English in English class, in addition to the third grade students to carry out organizational performance, the text retelling activities, often according to the teaching content, presentation and student learning and life related words.

\section{Collaborative curriculum design of English Teaching Innovation}

\section{Carry forward the spirit of innovation.}

Comrade Jiang Zemin pointed out: "innovation is the soul of a nation's progress, is an inexhaustible motive force for the prosperity of a country." In the gradual development of knowledge-based economy today, strengthen the cultivation of students' sense of innovation and innovation ability will be related to the future and destiny of the country. As the primary and secondary school teachers shoulder the historic mission of the basic education, we should know the special meaning of the innovation to the education today, so as to take the initiative to adapt to the trend of the times, and actively explore and implement innovative education. Innovative education is from the development of education, to inherit as the foundation, development for the purpose, in order to cultivate innovative talents for the basic value orientation of education. In succession, is to grasp the 
knowledge as the foundation; for the purpose of development is to use knowledge to solve problems to promote the development of students; to cultivate innovative talents as the basic value orientation is to attach importance to the training of the student's creativity in the process of solving the problems, and to cultivate creative talents. The innovation education absorbs the essence of the traditional education and the essence of modern education. It can be said that it is the inheritance and development of traditional education and modern education. The new era calls for the spirit of national innovation, it is necessary to put forward the corresponding requirements of education, innovative education is a reflection of the spirit of the times. Innovative teaching is the core of quality education. It will no longer require our teaching learning as a teaching objective, but to learn the knowledge as the essence of cognition, training thinking ability, master the scientific methods, so that students in the "discovery" in the process of knowledge is not simply to get the results, but stressed that the method to solve problems creatively and formed the spirit of inquiry.

\section{Creating teaching situations and cultivating students' creative thinking.}

The situation teaching is a unified conscious mental activity and unconscious mental activity, in the cognitive aspects of enlightening students so that students can be implied, conscious and unconscious education input. In primary school English teaching, the creation of situational awareness of the language, in the real situation in the use of language will receive an unexpected effect. We as teachers should be in the "new curriculum standard" under the guidance, by all means try to simulate the real situation, to create a real language environment to life, let the students in the autonomous learning, cooperative learning, inquiry learning is gradually formed, interest in learning English and hobbies, form positive use of English activities in a dynamic environment in real and the use of situational teaching in the primary school English teaching, can active classroom atmosphere, stimulate students' interest in learning, training students' language ability, and cultivate students' thinking ability and space imagination ability. To make students feel as if they are in the English world, and cultivate their creative thinking ability. For example, PEP Primary Book 3 / unit 4 my home AIDS, we in addition to the use of pictures, courseware and other ways to show, also can let students learn self-control before class with relevant, allow students to use plastic foam, cardboard, rubber mud and other materials to design a building or their ideal home, including study living, room, bedroom, bathroom, garage, etc., these homemade props can not only in the new teaching content, can also provide convenience for students to carry out the simulation, and the development of group activities, the creative thinking ability of students to improve the students' practical ability[3].

\section{Group cooperative learning, stimulate students' divergent thinking.}

Emphasis on the traditional teaching mode with the teacher as the center, take the classroom as the center, strengthen the training program, students in the traditional teaching mode cannot be used as the subject of learning in teaching, students' positive affection cannot be experienced, directly affect the students' cooperation spirit and innovation ability training. Cooperative learning makes the teaching process truly based on the students' autonomous learning, active exploration, the students a comprehensive, diverse subject in practice, and promote the development of their subjective spirit, practical ability and many other quality. The new curriculum standard points out that "this course advocate's task based teaching mode, so that students can achieve the goal of the task through perception, experience, practice, participation and cooperation under the guidance of teachers. In the learning process of emotional and strategic adjustment in order to form a positive learning attitude, and promote the improvement of the practical ability of language use". Therefore, English learning is a process of cooperative interaction, through the active participation and cooperation of children, to gain the ability to improve the practical application of language. Practice has proved that cooperative learning through such activities, improve the comprehensive participation of students, not only stimulate students' divergent thinking, but also cultivate their sense of cooperation, if the teacher can insist on cooperative learning of continuous exploration and innovation, not only can promote the development of students' language ability, improve the level of students' thinking, stimulate the students' creative ability of using the language, but also conducive to the establishment of a 
harmonious relationship between students and teachers, will also promote the improvement of teachers' teaching level of English. As in teaching "would you like I What" like d... You like Would... And so on, the students divided into several groups, the students according to the sentence pattern, the students in the exchange, discussion, into a wide variety of dialogue. Some of the text on the basis of the "I" m hungry/ thirsty. "some of the dialogue to treat the scene:" Welcome to my home. Come in and sit down. Would you like something to drink? "In their cooperation in practice, mutual inspiration, mutual discussion, thinking by concentration and divergence, and by the divergence and concentrated, individual thinking development in the collective wisdom.

\section{Clever arrangement of activities, the implementation of independent inquiry behavior.}

In the English Teaching in primary school, it is a new way to cultivate students' autonomous learning English. Inquiry classroom teaching is the classroom teaching mode which takes the student as the main body to discuss and study. The independent inquiry teaching in the "student oriented" teaching serves learning "ideas, trying to mobilize and exert students' learning enthusiasm and initiative, independent inquiry learning potential, cultivating students' innovative consciousness and practice ability. The students' active participation in the learning process is the most important feature of the autonomous inquiry learning. Without the active participation of students, there is no independent inquiry learning. The independent inquiry teaching that teachers must respect the students, pay attention to the interests of the students, as much as possible, to give students learning initiative, so as to arouse their learning enthusiasm, initiative and creativity. Give full play to the main role of students. In the process of teaching, teachers should always encourage students to try operation, communication, discussion, questioning, to ask the right questions; give the students to speak, to give students the opportunity to interact in the process to students. As much as possible to give the student independently, creating learning time and space, to form a lively and vivid learning situation. As in the teaching of color words, we can make students operate or allow students to observe with "black and red" what color is mixed together will not only let the students learn to observe, also said that the color words are very profound memories of black, red, and brown several. The spirit of innovation and the innovation ability is not a short duration of time of the preliminary work to cultivate students' innovation consciousness, and persist as long as the students really put in the main position, optimize the teaching structure, teaching method and teaching means to mobilize the enthusiasm of the students, cultivate students' subjectivity, initiative and creativity [4].

\section{Language learning and communication}

\section{Explanation of background knowledge.}

The content of the collaborative curriculum is an important part of the English language and the English national cultural background of the relevant knowledge to explain. Students learn English not only themselves, but also as a tool to communicate in English to be taken seriously. Teachers improve students' interest in learning English in the context of language and culture, so that they can obtain the subjective initiative of learning English. For example, the novel plays, movies, classic stories, landscape architecture, such as the emergence of the customs and habits to explain, you can demonstrate vivid and realistic display. Learn to distinguish the true and false of western culture in the process of learning. In the teaching practice, teachers can also enrich the classroom teaching atmosphere by using the multimedia technology. For example, with the help of multimedia teaching, the classroom teachers to become a guide, rather than dominate, teachers with voice, text, images and animation, three-dimensional show to the students, the teachers teaching and students learning process become vivid, communication between teachers and students, between students and both increased the teacher's feelings, and can make the teachers get creative inspiration in the process, but also can improve the learning efficiency of students, make students have a more solid impression for cultural knowledge, but also can improve the teaching effect. 


\section{Method of specification.}

Have seen such a sentence on the Internet: a person is not a society eliminated because of age, but because of the ability to lose the ability to learn. Yes, only to learn to keep pace with the times and then to keep pace with the times! Reform our old teaching methods to cultivate students' autonomous learning ability is the most critical. The current is a critical period of reform and development of basic education, advanced the concept of traditional and backward education idea and the reform of basic education, the new curriculum reform in the contradiction conflict, confrontation, still with a strong influence on people's concept about education and education, which produced some non humanity, non humane education management measures. For example, to work overtime, the sea tactics simplify education courses, discrimination against learning difficulties students, ignoring the cultivation of students' cultural quality and other practices to improve the students' test scores. In the current educational situation, many people think that the classroom teaching reform is not possible, education research can only retreat cannot solve practical problems, teaching department of school or even revoked. The middle school teaching experience proved that only through education scientific research to promote the reform of classroom teaching, in order to solve a series of scientific theories in the current elementary education reform and practical problems. So this is a good time to do scientific research of education, school leaders and teachers to strengthen the reform of our faith, advocate the ideal of education, in-depth study and exploration [5].

\section{Summary}

In the mode of innovation education, the teaching method of cooperative curriculum has got some effect in practice. This kind of teaching mode, not only has the characteristics and advantages of the western teaching system, but also can make full use of learning skills, is a kind of advanced western teaching methods and scientific means. I longed for the working state of students can take the initiative, active classroom, after-school initiative, active outside, and even talk, quarrel, have a sense of the expression of active, positive learning attitude, with rigorous logical thinking. I want my students to learn to be more effective, I asked the students to have a positive belief, and there is a clean mind. The gap between the students and the students in the mountain area can be reduced, and our students can have a better future. In the traditional mode of education, and the actual combination of innovation and reform. Not only to enable students to acquire more knowledge, but also to improve the resilience and personal qualities, in order to meet the needs of the future development.

\section{Acknowledgements}

This work is supported by Social Science Foundation of Liaoning Province (No. L15DWW005) and Bohai University Teaching Reform Project (No.BDJG15QNB002).

\section{References}

[1] Yang Junfeng. Usage mastery and communicative competence in language teaching in foreign language teaching and research the relationship between [J]. 1987 (06).

[2] Jiang Yanhong. Mining material, cultivation of new curriculum reading habits of [J]. students' good learning (below). 2014 (09).

[3] Li Dan. English teaching must cultivate students' practical communicative ability [J]. Journal of Shandong Institute of Commerce and Technology. 2003 (02).

[4] Wang Hui in English Teaching in the cultivation of students' practical communicative ability [J]. science and technology information (Scientific Research). 2007 (24).

[5] Guo Jing. How to improve the students' oral English communicative ability [J]. Journal of Chifeng University (Chinese philosophy and Social Science Edition). 2010 (07). 